\title{
INTELLECTUAL PROPERTY RIGHTS (IPR): AN OVERVIEW
}

\author{
Sreeragi R.G. \\ UGC Librarian \\ VTM NSS College, Dhanuvachapuram Thiruvananthapuram, Kerala
}

\section{Manuscript Info}

\section{Manuscript History}

Received: 08 November 2020

Final Accepted: 22 December 2020

Published: 10 January 2021

Online Published: February 2021

DOI: http://dx.doi.org/10.35337/EIJLITR.2021.1205

(C) Sreeragi R.G. The Author. This is an open access article under the terms of the Creative Commons Attribution License 4.0, which allows use, distribution and reproduction in any medium, provided the original work is properly cited.

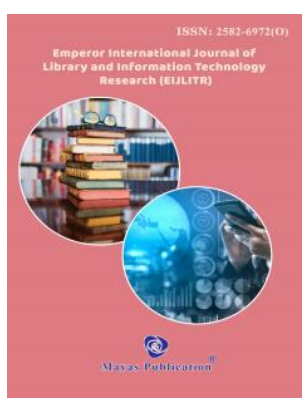

\section{Abstract}

All tangible and intangible creations of human mind and intellect can be considered as the assets of humanity. These manifestations come under the category of Intellectual Property Rights (IPR). Research and scientific activities trigger the production of intellectual properties in many ways and impetus as a catalyst of the industrial and economic growth of the nation itself. These creations are being protected by law over a significant timeframe. The creation of wide assortment of products is legitimately ensured with the makers themselves. Additionally, it offers opportunity to share and distribute knowledge for the prosperity of the society. To maintain equilibrium, these rights are conceded for a specific period of time. Patents, copyright, trademarks, geographical indicators etc are altogether coming under the umbrella term IPR. In order to get privilege over the innovations, it ought to be filed for granting rights as per the laws exist in the country. The presents study enquires the different categories of intellectual properties and the duration up to which the inventions will be legally secured once registered.

\section{INTRODUCTION}

The Intellectual Property Rights (IPR) has a key role in the development of each country. The scientists from research and development institutions are the major contributors to the field. There are diverse intellectual properties protected by independent laws in India. The forms of IPR are Patents, Copyrights, Trademarks, Industrial designs, Geographical indications, Layout Design of Integrated Circuits, Protection of plant varieties and Farmer's Rights and Protection of undisclosed information/Trade secrets (Intellectual Property Facts-Make in India.(n.d.))

\section{Patent}

Patent is an exclusive right granted by the government to the innovators to create, use, sell, industrial production, and import. It prevent others from doing the likewise without seeking prior consent, within the boundaries of the nation. Patent is granted for a new product or a process which involves industrial applications. All inventions are not patentable. The innovations coming under section 3 and 4 of the Indian Parliament Act, 1970 are exempted from giving patent. 
The inventor or his assignee is permitted to apply for patents. The incentives the inventor get is the recognition of their creativity and encouragement for engaging in such future endeavours. A patent is granted by the National Patent Office or the offices at regional centres in the country. The inventions are protected for a long time from the date of filing for the legal permission. In India, twenty years of coverage is given for each patent.

\section{Copyrights}

A legal right granted to the owner of a literary, artistic or scientific work to make use of it, is widely known as copyright. The protection authorize others also to make use of it for reproduction and public demonstration by obtaining prior permission from the authors. Only the expression of ideas are protected by this law and these ideas are free to use to all as their own interest. The works such as literary, dramatic, musical work, computer programs, software, drawings, paintings, cinematographic films and recordings are cover under copyright.

Literary works are protected up to sixty years after the life time of the author. The creations like cinematographic recordings, anonymous publications, government publications, works by international agencies get sixty years of legitimate inclusion (Intellectual Property Risks in India.(n.d.)). For a term of a quarter century from the date of publication, the broadcasting media will be protected.

The copyright office under the immediate control of the registrar of copyrights, grants the legal consent to the person concerned to the production of the work. In India, copyright was enacted by law in 1957 and has got amendments in 1983, 1984, 1992, 1994, 1999 and 2012.

\section{Trademarks}

Some sort of indicator or a sign that recall us about a product or an organization. These are distinctive and unique in nature helping to identify the source of specific products from their competitors in the field. It makes easy for people to identify the exact one for which they are searching from a range of similar enterprises. Trademarks may consist of alphabets, numerals, words/combination of words, symbols, drawings, three dimensional signs and voice recordings. Even colours and fragrances are being used as distinguishable trademarks in the industry (IPR lawIndia-IndianIPLaw Resources- CIPRANLSIU, Bengaluru.(n.d.)).

Trademarks are mainly categorized into three. They are service marks, collective marks and certification marks. Service marks are the symbols or images which represent the identity of the service offered from a specific institution. Examples are The State Bank of India, LIC, etc. Collective marks are set by certain associations which represent a specific group having certain qualities and offer specialized services to the public, like doctors, engineers and lawyers. Certification marks are given as a means of measuring standards in quality. Any individual who applies for the certification should fulfill the minimum standards or guidelines stipulated by the issuing authority. Eg: ISO 9000. Application for registration of trademark ought to be filed with National or Regional Trademark office. In India, the Trade Marks act came into being in 1999 and had a revision in 2010.

Trademark will be granted for a period of ten years initially and are permissible to renew every ten years according to the necessity. Even though it is prudent to all business start ups, registration for trademark is not mandatory.

\section{Industrial Designs}

The aesthetic aspects like pattern, colour or lines of two dimensional or three- dimensional features of an article are protected under the category of Industrial Designs. There are no technical factors regarding Industrial Designs. The design should be novel and not utilised anywhere even outside the country, when trying to file for the registration (Pradeep Kumar, 2018). The known shapes or pattern experimented on new context which involves any mental activity for conceptualization maybe considered for granting Industrial Designs. Such articles must have Independent existence from the designs applied to it. The maximum period of protection will be of fifteen years in total. At the initial stage, the period will be for ten years and it tends to be extended for five years duration by paying 
renewal fee. The power of issuing registration is vested with the Controller of Patents and Designs situated at the Intellectual Property Office, Kolkata.

\section{Geographical Indications}

The Geographical Indication is a sign of merchandise possesses some specific qualities and known in the name of a particular geographical area as its origin and a similar product may not be available elsewhere satisfying all these characteristics. It is assigned along with the name of the place from which it is originated. This can be used for a wide variety of products. Among them agricultural products like Darjeeling tea, Alphonso mango, Mysore sandel, Pokkali rice, and Nagpur orange are widely recognised in India and foreign countries. Kancheepuram Silk and Aranmula kannadi are exceptional and familiar to public as the names of genuine and trustable products guaranteeing certain qualities.

The associations or organizations legally registered which works for the well- being of the farmers or the producers or representing to protect their interests, can apply for the registration of a Geographical indication (GI). A rancher of the product can be registered as an authorized user of GI and all registered users have equal rights. The exact intension behind assigning GI is to prevent worthless imitation of certain products purely on commercial thoughts (Intellectual Property Risks in India. (n.d.). The legislation covering Geographical Indication of Goods (Registration and Protection Act) came into force in 1999, offers a GI for an initial term of ten years which can be renewed for a limitless period upon demand. The office of the Registrar of Geographical Indications, Chennai receives all requests on GI in the country. When an authorized user dies, the right devolves on his successor. At the same time, transmission, assignment and licensing on GI are not permitted legally.

\section{Protection of new Plant Varieties and Farmer's Rights (PPVFR)}

The rights under the Protection of new Plant Varieties and Farmer's Rights (PPVFR) cover a wide chain of rights conferred exclusively for specific groups, such as Breeders' rights, Researchers' rights and Farmers' rights. Breeder will have rights to cultivate, sell, and market the product. Importing and exporting goods are also permissible. A researcher can use any of the registered varieties, for research purpose or conducting experiments. A researcher has to get consent from the breeder of the initial source of a variety, on experiment, for conducting further development. In addition, farmers' interest in being a part of the development of a plant variety is entitled with the registration and protection. The farmers' general works and eligibility to get honours and awards for conservation of plant genetic resources and wild family of economic plants are also protected by law. The office of the Registrar of Protection of Plant Varieties and Farmer's Rights authority in New Delhi is the authorized registration centre for the protection of all rights for plant varieties and farmers guaranteed by law. The registration process involves complex procedures and it varying depends on the type of legal right required. Once it is granted the rights are protected for a certain period of time ( Pradeep Kumar, 2018).

\section{Layout design of Integrated Circuits}

The designing of layout of an integrated circuit is the process involving a two or three dimensional layout or the topography of an IC. It is also termed as mask work. This structure consists of elements include transistors, other circuitry elements and lead wires connecting to them. In order to get protection for semiconductor IC layout designs, an act came into force in India in the year 2000. In the event, the layout of a circuit found not original, commercially exploited anywhere in India, inherently not distinctive or not in a distinguishable form from registered layout design will not be considered for registration under this act. The period of legal coverage will be of ten years. The Semiconductor Integrated Circuit Layout Design Registry at New Delhi is the issuing authority of rights regarding design of Integrated Circuits.

\section{Protection of undisclosed information/Trade Secrets}

The trade secrets of an enterprise provide a competitive edge in business. A trade secret may refer to a chemical product, a combination of some elements or single chemical formulae related to the industry. Taking some measures like restricting access to the information and maintaining non-disclosure agreements among the employees in the industry are part of protecting trade secrets. There is no specific legislation in India for protecting undisclosed information. For example, the Coco-Cola has a trade secret. 
The formulae for the taste and the combination of Coco-Cola, is kept as secret in the vault of a bank in Georgia, in the name of 'Merchandise 7X (Pradeep Kumar, S. (Ed.). (2018).

\section{CONCLUSION}

The Intellectual Property Rights has a key role in fostering research and innovations of every nation (Why Intellectual Property Rights are Important in Current Era?, 2019). It has crucial influence on international and national trade. These rights protect both individual and national interest through giving opportunity for economic growth. Always, the unique expression of ideas or products is being important in all commercial endeavours. In tody's digital world, there are more chances of stealing trade secrets or illegal use of registered properties, as the entire world is connected with networks. Lose of Intellectual Properties may be detrimental for the overall development of the whole nation itself. For protecting the wealth of the nation, stringent laws should be enacted in all fields associated with handling Intellectual properties.

\section{REFERENCE}

1. INTELLECTUAL PROPERTY FACTS - Make In India. (n.d.). Www.Makeinindia.com.

2. Retrieved January 17, 2021, from https://www.makeinindia.com/policy/intellectual- propertyfacts

3. Intellectual Property Risks in India. (n.d.). UK India Business Council. https://www.ukibc.com/india-guide/how-india/intellectual-property/

4. IPR Law India - Indian IP Law Resources - CIPRA - NLSIU, Bengaluru. (n.d.). IPR Law India Indian IP Law Resources. Retrieved January 17, 2021, from https://iprlawindia.org/

5. Jajpura, L., Singh, B., \& Nayak, R. (2017). An Introduction to Intellectual Property Rights and their Importance in Indian Context. Journal of Intellectual Property Rights, 22, 32-41. http:/ / docs.manupatra.in/newsline/articles/Upload/41C26FED-7AFE-40EA-87364E6C516917AE.pdf

6. Pradeep Kumar, S. (Ed.). (2018). Patent Information Centre-KSCSTE.

7. Why Intellectual Property Rights are Important in Current Era? (2019, June 21). Blog | Kashish IPR | Intellectual Property Rights Law Firm. https://www.kashishipr.com/blog/whyintellectual-property-rights-are-important-in-current-era/ 